International Journal of Civil Engineering and Technology (IJCIET)

Volume 9, Issue 7, July 2018, pp. 867-873, Article ID: IJCIET_09_07_090

Available online at http://www.iaeme.com/ijciet/issues.asp?JType=IJCIET\&VType=9\&IType=7

ISSN Print: 0976-6308 and ISSN Online: 0976-6316

(C) IAEME Publication

Scopus Indexed

\title{
AN IMPLEMENTATION OF A FILTER DESIGN PASSIVE LC IN REDUCE A CURRENT HARMONISA
}

\author{
Maharani Putri, Pristisal Wibowo, Solly Aryza, Andysah Putera Utama Siahaan, \\ Rusiadi \\ Lecturer of Universitas Pembangunan Panca Budi, Medan, Indonesia
}

\begin{abstract}
The problem of electric power quality is a matter of changing the form of voltage, current or frequency that can cause failure of equipment, either utility equipment or consumer property. Components of household equipment there are many nonlinear loads, one of which Mixer. Even a load nonlinear current waveform and voltage is not sinusoidal. Due to the use of household appliances such as mixers, it will cause harmonics problems that can damage the electrical system equipment. This study analyzes the percentage value of harmonics in Mixer and reduces harmonics according to standard. Measurements made before the use of LC passive filter yield total current harmonic distortion value (THDi) is $61.48 \%$, while after passive filter use LC the THDi percentage becomes $23.75 \%$. The order of harmonic current in the 3rd order mixer (IHDi) is 0.4185 A not according to standard, after the use of LC passive filter to 0.088 $A$ and it is in accordance with the desired standard, and with the use of passive filter $L C$, the power factor value becomes better than 0.75 to 0.98 .
\end{abstract}

Key words: Mixer, Harmonic, THDi, and THDv, Standard IEC61000-3-2 Class D.

Cite this Article: Maharani Putri, Pristisal Wibowo, Solly Aryza, Andysah Putera Utama Siahaan, Rusiadi, An Implementation of A Filter Design Passive LC In Reduce A Current Harmonisa, International Journal of Civil Engineering and Technology, 9(7), 2018, pp. 867-873.

http://www.iaeme.com/ijciet/issues.asp?JType=IJCIET\&VType=9\&IType=7

\section{INTRODUCTION}

Harmonic is a phenomenon generated from the operation of electrical loads that mostly result from nonlinear loads, which will form a wave of high frequency. The frequency is a multiple of its fundamental frequency of $50 \mathrm{~Hz}$ so that the current waveform and the supposed voltage are pure sinusoidal will be defective due to harmonic distortion that occurs. Harmonics was usually defined as sine waves (currents and voltages) having integer frequency (integer) frequencies of their fundamental frequencies [1]. 
Electronic equipment such as Mixer is a non-linear load connected to an electrical utility causing an increase in harmonics in the electrical system that supplies it [2]. Total Harmonic Distortion (THD) of an electrical load can cause poor system power quality, low power factor, a distorted voltage waveform, increased system power loss, overheating of the transformer, inefficient use of electrical energy, and may affect the performance of other equipment using the power source [3].

The magnitude of the percentage of harmonics produced by Mixer not only gives an adverse impact to the mixer itself but also provides a bad influence on the system. Harmonics can damage the quality of rotation and also adversely affect the electric power equipment that is the value of RMS currents and higher voltage, the peak value (current) and higher voltage and frequency of the system down. While on the system, the influence of harmonics, among others: loading and the working transformer will increase weight, technical losses on the more extensive network, the use of electrical energy becomes inefficient, and the performance of other equipment was also disrupted [4].

\section{LITERATURE REVIEW}

Factors affecting the quality of electrical power include [2], [5].

1. Electric consumers become increasingly aware of power quality issues such as voltage fluctuations, interruptions, and transients. Also, many governments in a country have revised their policies to further enhance the quality of power by established limits and standards.

1. The emphasis on overall power system efficiency has led to the use of high-efficiency devices, adjustable-speed motor drives and parallel capacitors to correct power factor and reduce losses. As a result, there is an increase in harmonic levels in power systems that threaten the operation, reliability, and security of the system.

2. Modern equipment loads use microprocessor-based controllers and power electronics devices that are more sensitive to changes in power quality.

3. Automation and efficiency depend on digital components requiring direct current supply. Since the power generated and transmitted is AC power, the AC power supply must be converted to DC first to be used by DC loads. Therefore, it will be much needed a converter that can further increase the harmonic level and can cause the fundamental wave distortion becomes more severe.

A mixer is used for facilitating household work, especially to mix cookie dough matrials, bread, and so forth [6]. Design mixer reasonably modern. Has several components in it to support the optimal performance of a Mixer. The Mixers are one of the most modern types of household appliances used to lighten the workload of household chores. Mixer serves as a mixer or mixer of foodstuffs to make bread dough, cake, or the like. A mixer is only used as a household appliance, but it is not possible to use a mixer on a large scale as a home industry [7].

Mixer working principle is to convert electrical energy into mechanical energy by flowing electric current to switch speed selector switch and then rushed back to the driving force. The driving force present in the mixer is included in the induction motor of the wound rotor (wound rotor induction motor) [5].

To determineat at a value of Total Harmonic Distortion (THD) from the formulation of fourier series analysis for voltage and current in the function of time [8]

$$
\begin{aligned}
& v(t)=V o+\sum_{n=1}^{\infty} V_{n} \operatorname{Cos}\left(n \omega t+\theta_{n}\right) \\
& i(t)=i o+\sum_{n=1}^{\infty} I_{n} \operatorname{Cos}\left(n \omega t+\theta_{n}\right)
\end{aligned}
$$


For the RMS voltage and current value of the sinusoidal wave we can calculate the wave peak value divided by $\sqrt{2}$ and fourier for the voltage and current shown Equation (5 and 6) [9]:

$$
\begin{gathered}
V_{R M S}=V_{o}{ }^{2}+\sqrt{\sum_{n=1}^{\infty}\left(\frac{V_{n}}{\sqrt{2}}\right)^{2}} \\
I_{R M S}=I_{o}{ }^{2}+\sqrt{\sum_{n=1}^{\infty}\left(\frac{I_{n}}{\sqrt{2}}\right)^{2}}
\end{gathered}
$$

The value of Total Harmonic Distortion (THD) for voltage and current is shown in Equations (7 and 8) ie:

$$
T_{v}=\frac{\sqrt{\sum_{n=2}^{\infty}\left(\frac{V_{n}}{\sqrt{2}}\right)^{2}}}{\frac{V_{1}}{\sqrt{2}}}=\frac{\sqrt{\sum_{n=2}^{\infty}(V n)^{2}}}{V_{1}}
$$

So the current RMS to THDI becomes:

$$
I_{R M S}=I_{1, R M S} \sqrt{\left(1+T H D_{I}^{2}\right)}
$$

Table 1 Standard harmonic current for class D equipment

\begin{tabular}{|c|c|c|}
\hline $\begin{array}{c}\text { Harmonisa } \\
\text { to-n }\end{array}$ & $\begin{array}{c}\text { Current harmonisa maximum } \\
(\mathbf{m A} / \mathbf{W})\end{array}$ & $\begin{array}{c}\text { Current harmonisa maximum } \\
(\mathbf{A})\end{array}$ \\
\hline $75<\mathrm{P}<600 \mathrm{~W}$ & & $\mathrm{P}>600 \mathrm{~W}$ \\
\hline 3 & 3,4 & 2,30 \\
\hline 5 & 1,9 & 1,14 \\
\hline 7 & 1,0 & 0,77 \\
\hline 9 & 0,5 & 0,40 \\
\hline 11 & 0,35 & 0,33 \\
\hline 13 & 0,296 & 0,21 \\
\hline $15 \leq \mathrm{n} \leq 39$ & $3,85 / \mathrm{n}$ & $2,25 / \mathrm{n}$ \\
\hline
\end{tabular}

\section{METHODOLOGY OF RESEARCH.}

The method used in this study is to perform Measurement and retrieval of data performed directly. Measurement and retrieval of data are done directly to the field by using a measuring tool called Power Quality Analyzer. Data communication from Power Quality Analyzer to the computer is done via USB. This data communication packet is displayed in list and graph form directly, and the data can be stored on the computer.

The equipment used in measuring the mixer is the Power Quality Analyzer Fluke 43B, laptop, and connecting cable. Fluke 43B Power Quality Analyzer gauge can be shown by Figure 1 as follows:

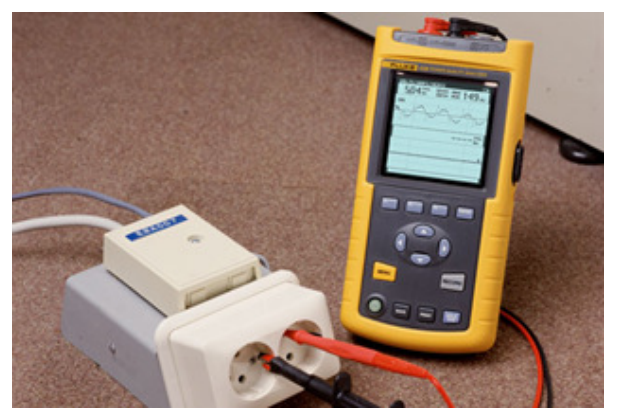

Figure 1 Power Quality Analyzer Fluke 43B 
Then the result of the measurement is analyzed and adjusted with the IEC61000-3-2 Standard and examined its effect on power quality. The data obtained can be seen in Table 2 .

Tables 2 Mixer Measurement Data

\begin{tabular}{|c|c|c|}
\hline Parameter & Satuan & Mixer \\
\hline U (Phase Voltage) & Volt & 226.3 \\
\hline I (Phase Current) & Ampere & 0.75 \\
\hline S (Apparent Power) & VA & 126.5 \\
\hline P (Active Power) & W & 110 \\
\hline Q (Reactive Power) & VAR & 58.5 \\
\hline PF (Power Factor) & - & 0.75 \\
\hline Cos Phi & - & 0.86 \\
\hline THDv & $\%$ & 1.7 \\
\hline THDi & $\%$ & 59.4 \\
\hline Freq & $\mathrm{Hz}$ & 50.01 \\
\hline
\end{tabular}

In Table 3 we can see the Mixer current harmonic measurement data from the 3 rd order to the 15th order. Classification of harmonic current based on IEC6100-3-2 Class D standard. Where the value of current at 3rd order is not by IEC61000-3-2 Class D standard is 0.4185 A.

Tables 3 Classification of measurement harmonics currents Based on IEC61000-3-2 Class D standard

\begin{tabular}{|c|c|c|c|c|}
\hline \multirow{2}{*}{$\begin{array}{c}\text { Harmonisa } \\
\text { with-n }\end{array}$} & \multicolumn{2}{|c|}{$\begin{array}{c}\text { Harmonic current } \\
\text { constraint Standard } \\
\text { IEC61000-3-2 (Mixer 110 } \\
\text { W) }\end{array}$} & $\begin{array}{c}\text { Harmonic current } \\
\text { Measurement results } \\
\text { (A) }\end{array}$ & Information \\
\cline { 2 - 3 } & $(\mathrm{mA} / \mathrm{W})$ & $(\mathrm{A})$ & 0.4185 & Not standart \\
\hline $\mathbf{3}$ & 3.4 & 0.374 & 0.159 & Standar \\
\hline $\mathbf{5}$ & 1.9 & 0.209 & 0.0465 & Standar \\
\hline $\mathbf{7}$ & 1 & 0.11 & 0.0255 & Standar \\
\hline $\mathbf{9}$ & 0.5 & 0.055 & 0.01425 & Standar \\
\hline $\mathbf{1 1}$ & 0.35 & 0.0385 & 0.0009 & Standar \\
\hline $\mathbf{1 3}$ & 0.296 & 0.03256 & 0.00075 & Standar \\
\hline $\mathbf{1 5} \leq \mathbf{n} \leq \mathbf{3 9}$ & 3.85 & 0.4235 & & \\
\hline
\end{tabular}

\subsection{FLOWCHART OF RESESRCH.}

The research flow diagram starts from data collection and harmonic measurement and then the measurement results are adjusted to IEC1000-3-2 Class D standard. Then reduce with the addition of passive LC filter simulated using Matlab / Simulink as shown in Figure 2. 


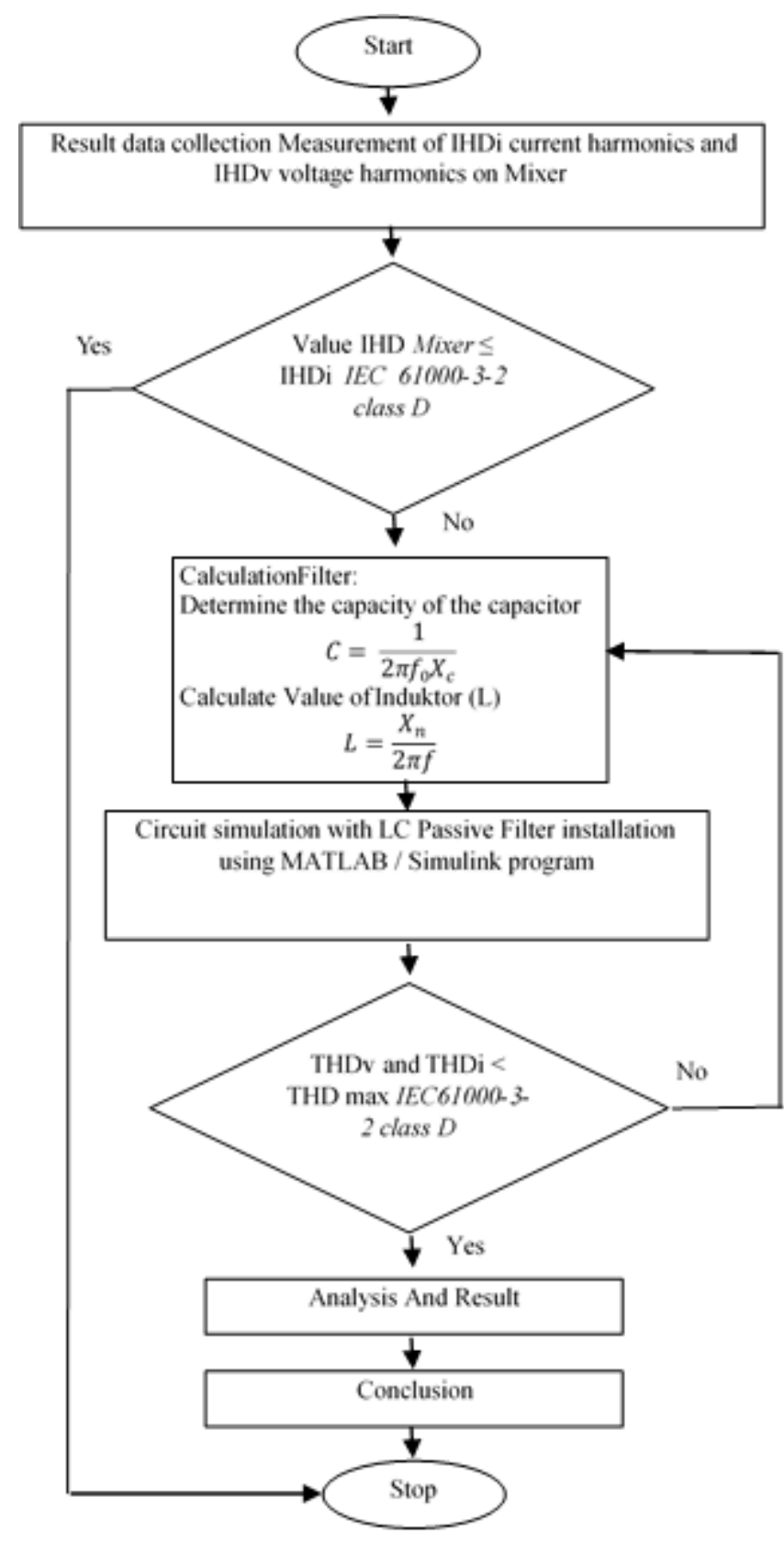

Figures 2 Flow Chart of Research

\section{ANALYSIS AND RESULTS}

The simulation used in this research is using Matlab / Simulink program by implementing LC passive filter which is connected in parallel to the circuit. Obtained simulation results after use of LC passive filter, where total distortion of THDi current harmonic is $23,75 \%$ from before use equal to $61,48 \%$. Flow waveform and harmonic spectrum prior to the use of LC passive filter can be seen in Figures 3 and 4. 


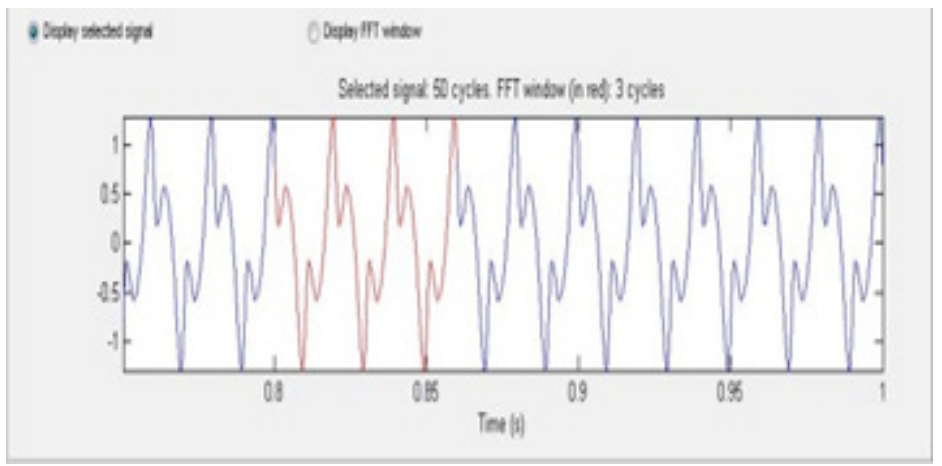

Figures 3 Flow Wave Form Before Passive LC Filter Usage

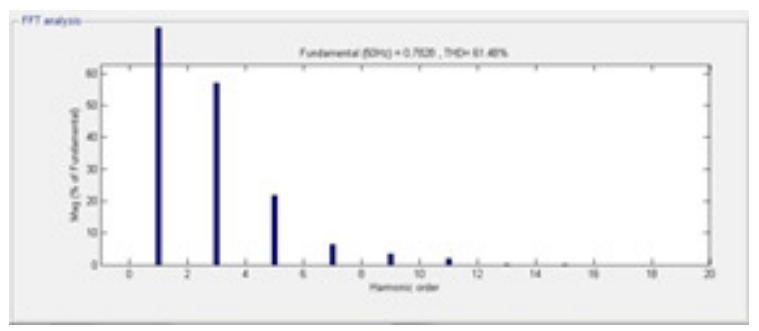

Figures 4 Spectrum Current Before Using Passive LC Filter

Flow waveform and harmonic spectrum after passive filter use LC can be seen in Figures 5 and 6 .



Figures 5 Flow Wave Form After Using Passive LC Filter

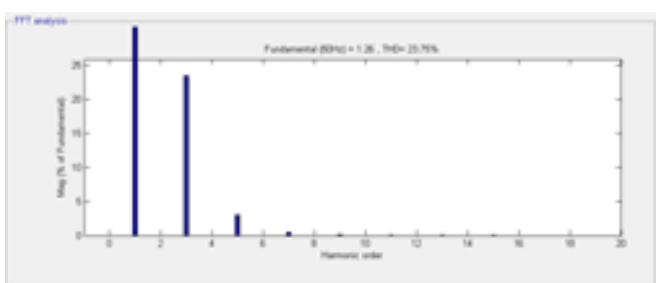

Figures 6 Current Spectrum After Passive LC Filter Usage

\section{CONCLUSION}

This research concludes that the measured Mixer produces a total value of $60.48 \%$ of the harmonic distortion voltage (THDi). After passive filter use LC THDi to 23,56\%. For harmonious order (IHDi) at the 3rd order before the use of LC passive filter of 0.4185, A while after use to $0.088 \mathrm{~A}$ so that the results obtained according to IEC61000-3-2 Class D standards are by standard and power factor produced to 0.98 . 


\section{REFERENCES}

[1] M. A. Magzoub, N. B. Saad, and R. B. Ibrahim, "Efficiency Improvement of Induction Motor Variable Speed Drive Using a Hybrid Fuzzy-fuzzy Controller," in Energy Procedia, 2015, vol. 75, pp. 1529-1535.

[2] S. Aryza, M. Irwanto, Z. Lubis, A. P. U. Siahaan, R. Rahim, and M. Furqan, “A Novelty Design Of Minimization Of Electrical Losses In A Vector Controlled Induction Machine Drive,” IOP Conf. Ser. Mater. Sci. Eng., vol. 300, no. 1, p. 12067, 2018.

[3] P. Wibowo, "Analisis Filter Pasif Single Tuned Untuk Mengurangi Arus Harmonisa Pada Mixer.".

[4] S. Aryza, A. N. Abdalla, Z. Khalidin, and Z. Lubis, "Adaptive speed estimation of induction motor based on neural network inverse control," Procedia Eng., vol. 15, pp. 4188-4193, 2011.

[5] S. Aryza, M. Irwanto, Z. Lubis, A. Putera, and U. Siahaan, "A Novelty Stability Of Electrical System Single Machine Based Runge Kutta Orde 4 Method," IOSR J. Electr. Electron. Eng. Ver. II, vol. 12, no. 4, pp. 2278-1676, 2017.

[6] P. Wibowo, S. A. Lubis, . Hermansyah, . Hamdani, and Z. Tharo, "Smart Home Security System Design Sensor Based on Pir and Microcontroller," Int. J. Glob. Sustain., vol. 1, no. 1, p. 67, 2017.

[7] S. A. Lubis et al., "APPLICATION HYBRID ECO CAMPUS VEHICLE BASED ON SOLAR POWER," vol. 3, no. 2, 2015.

[8] S. Speed et al., "Shaft speed, load torque and rotor flux estimation of induction motor drive using an extended Luenberger observer," Electr. Mach. Drives, 1993. Sixth Int. Conf. (Conf. Publ. No. 376), no. 3, pp. 179-184, 1993.

[9] Ravirajsinh S Vaghela and Dr. Atul Gonsai, Filter Design For Improvement of Interference on Adjacent Frequency, International Journal of Electronics and Communication Engineering and Technology, 8(3), 2017, pp. 10-16.

[10] B. Ravi Teja, B. Rama Krishna, V.Gowtham and M. Chakravarthi, Control Algorithm of Shunt Active Power Filter for Harmonic Mitigation Using Indirect Current Control Technique. International Journal of Electrical Engineering \& Technology, 9(2), 2018, pp. $37-48$.

[11] Chandram Karri, Soujanya Kuchana, Detection and Quantification of Harmonic Emissions in Doubly Fed Induction Generator. International Journal of Electrical Engineering \& Technology, 8(5), 2017, pp. 20-31.

[12] B. Ramya, T. Srinivasarao, T. Mahesh babu, P.L.Pravallika, G. Narsi Reddy and Prabhakara Sharma Pidatala. A novel approach of harmonic elimination in a square-wave inverter for low and medium-voltage applications. International Journal of Electrical Engineering \& Technology, 8(2), 2017, pp. 36-48

[13] S. Aryza, M. Irwanto, Z. Lubis, and A. P. U. Siahaan, "A Novelty Stability Of Electrical System Single Machine Based Runge Kutta Orde 4 Method." 